\title{
2: 73967741-74001666
}

National Cancer Institute

\section{Source}

National Cancer Institute. 2: 73967741-74001666. NCI Thesaurus. Code C41689.

Physical location of AMSH_Gene 